\title{
ANALISIS SURVIVAL PADA FINANCIAL DISTRESS MENGGUNAKAN MODEL COX HAZARD
}

\author{
Jasmine Yolanda ${ }^{1}$, Farida Titik Kristanti ${ }^{2}$ \\ Universitas Telkom
}

\begin{abstract}
Companies need a system to prevent the emergence of financial distress to provide early warning if there are financial problems in the company. The research carried out aims to determine how much impact liquidity, leverage, independent commissioners, institutional ownership, managerial ownership, intellectual capital have on financial distress. The selected population is the companies included in the property, real estate, and building construction sector as well as the utility and transportation infrastructure sector for the 2009-2018 period. Purposive sampling technique is used in sampling by obtaining 56 samples. The analysis technique uses survival analysis with Cox Proportional Hazard model. Based on the results of data processing leverage and intellectual capital have a significant impact on financial distress.

Keywords $\quad$ : Corporate Governance; Financial Distress; Financial Ratios; Intellectual Capital.

Correspondence to : jyoland.56@gmail.com

\section{ABSTRAK}

Perusahaan memerlukan sistem untuk mengantisipasi timbulnya financial distress guna memberikan peringatan dini apabila ada masalah keuangan pada perusahaan. Riset yang dilakukan tujuannya adalah mengetahui seberapa besar dampak likuiditas, leverage, komisaris independen, kepemilikan institusional, manajerial, intellectual capital terhadap financial distress. Populasi yang dipilih yakni perusahaan yang termasuk ke dalam bidang properti, real estate, dan konstruksi serta infrastruktur utilitas dan transportasi periode 2009-2018. Pengambilan sampelnya memakai teknik purposive sampling dan memperoleh 56 sampel. Teknik analisisnya memakai analisis survival dengan model Cox Proportional Hazard. Berdasarkan hasil pengolahan data leverage dan intellectual capital mempunyai dampak yang signifikan pada financial distress.
\end{abstract}

Kata kunci $\quad$ : corporate governance; financial distress; intellectual capital;

Korespondensi $\quad$ : $\quad$ jyoland.56@gmail.com

\section{PENDAHULUAN}

Kondisi tingkat persaingan perusahaan yang menjadi semakin kompetitif mengakibatkan perusahaan dituntut untuk bisa mempertahankan kelangsungan hidup perusahaan agar dapat bersaing dengan kompetitor lain guna menjaga stabilitas perusahaan. Oleh karena itu, perusahaan dipaksa untuk bisa beradaptasi dengan tanggap terhadap perkembangan ekonomi sehingga dapat mengetahui keinginan yang diinginkan oleh pasar. Perusahaan yang dinilai baik secara laporan keuangan belum bisa menjamin akan kelangsungan hidup perusahaan (going concern) bisa saja periode selanjutnya perusahaan tersebut dinyatakan 


\section{BALANCE : Economic, Business, Management, and Accounting Journal}

Vol. XVII No. 2 |Bulan Juli tahun 2020

bangkrut. Maraknya perusahaan yang tidak sanggup berkompetisi dengan kompetitor lainnya dan tidak dapat mengikuti perkembangan ekonomi yang terjadi akibatnya keuangan perusahaan akan sulit.

Financial distress ialah memburuknya situasi keuangan yang terjadinya sebelum kebangkrutan sehingga terancam tidak bisa mempertahankan kelangsungan usahanya atau bangkrut (Platt \& Platt, 2002). Kondisi kinerja keuangan yang buruk berakibat pada penurunan efisiensi manajemen akan membuat hilangnya pelanggan dan penyuplai bisnis, hal ini terjadi karena manajemen hanya fokus dalam penyelesaian permasalahan keuangan (Cinantya \& Merkusiwati, 2015). Maka kestabilan kinerja keuangan diperlukan dalam pengawasan terhadap aktivitas bisnis agar meminimalisir risiko perusahaan mengalami kondisi financial distress (Saleh, 2018). Beberapa cara digunakan untuk mengukur financial distress seperti univariat, multivariat, regresi logistik, decision tree, ANN, dan analisis survival. Dalam ini, peneliti menggunakan metode analisis survival karena metode ini masih jarang dipakai dalam memperkirakan financial distress di Indonesia. Analisis survival ialah metode statistik yang bertujuan untuk pengamatan data dari suatu kejadian (event) apakah mampu mempertahankan kelangsungan hidup sampai pada periode waktu tertentu (Kristanti et al., 2016). Indikator keberhasilan suatu perusahaan dapat dilihat dari EPS perusahaan, semakin besar nilai EPS maka para pemegang saham tertarik untuk menginvestasikan modal kepada perusahaan (Aletheari \& Jati, 2016).

Korporasi yang memiliki EPS negatif dikategorikan kedalam kelompok yang terindikasi terjadi financial distress. Apabila nilai EPS dalam perusahaan tersebut bernilai negatif dapat dinilai dengan poin 1 sedangkan jika tidak bernilai negatif dinilai dengan poin 0 (Kristanti et al., 2016). Keuntungan dan kerugian yang didapatkan perusahaan dalam periode yang berkaitan mampu menggambarkan sistem kerja perusahaan di masa lalu dan ke depannya dengan EPS negatif (Widhiari \& Merkusiwati, 2015). Ini selaras dengan riset oleh Kristanti et al. (2016) menggunakan indikator EPS negatif.

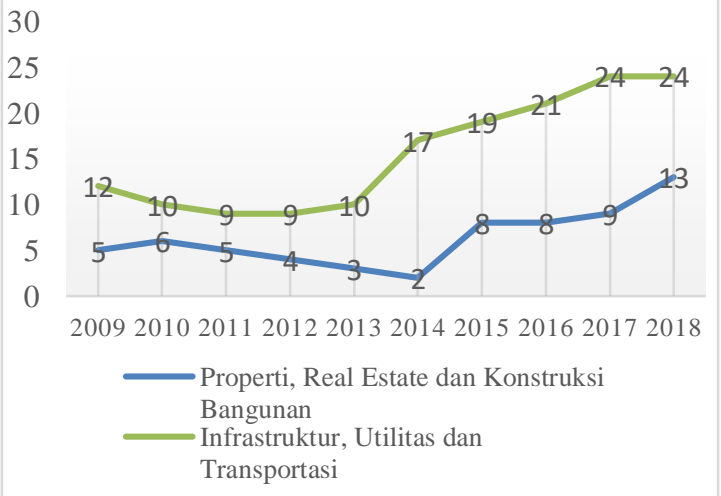

Gambar 1. Jumlah Perusahaan yang Memiliki EPS Negatif 2009-2018

Riset ini menggunakan dua sektor yang tercatat pada BEI yakni bidang properti dan infrastruktur selama 10 tahun. Terlihat pada Gambar 1 menunjukkan bahwa sektor properti cenderung mengalami fluktuatif setiap tahunnya perusahaan yang memiliki EPS periode 2009-2018. Hingga pada tahun 2015-2018 perusahaan yang memiliki EPS negatif mengalami peningkatan hingga puncaknya di tahun 2018 sebanyak 13 perusahaan dari 72 perusahaan yang terdaftar pada BEI. Sedangkan, pada sektor infrastruktur cenderung mengalami peningkatan EPS negatif pada tahun 20092018. Kondisi perusahaan yang mengalami EPS negatif terus mengalami peningkatan yang signifikan mulai dari tahun 2014-2018. Pada tahun 2017-2018 menjadi tahun yang memiliki EPS negatif terbanyak yaitu 24 perusahaan dari 61 perusahaan yang terdaftar pada BEI.

Berdasarkan fenomena yang terjadi, EPS negatif sudah cukup menggambarkan bahwa perusahaan dikhawatirkan akan mengarahkan pada kondisi kesulitan 
Vol. XVII No. 2 |Bulan Juli tahun 2020

keuangan. Jika kondisi ini tidak ditanggapi dengan cepat akan berakibat para investor berhati-hati untuk tahun berikutnya dalam melakukan investasi serta menjadikan nilai EPS sebagai dasar pertimbangan dalam berinvestasi. Perusahaan membutuhkan sistem yang dapat mencegah munculnya financial distress guna memberikan peringatan jika ada masalah keuangan pada perusahaan.

Banyak riset terdahulu yang telah mengkaji dalam memprediksi financial distress tetapi masih ada yang menunjukkan inkonsistensi pada beberapa variabel. Maka, Penulis ingin mengkaji ulang terhadap berbagai variabel yang memiliki inkonsistensi pada penelitian terdahulu. Riset ini bertujuan untuk menilai besarnya dampak likuiditas, leverage, komisaris independen, kepemilikan institusional, kepemilikan manajerial, dan intellectual capital pada financial distress.

\section{Teori Agensi}

Teori keagenan menjelaskan mengenai ikatan antara owner perusahaannya sebagai pemberi wewenang dan manajemen perusahaan yang menjadi pihak penerima wewenang. Pemilik perusahaan (principal) bertugas sebagai pemberi amanah dalam pendelegasian tanggung jawab atas decision making pada manajer untuk melakukan fungsi yang relevan dengan kesepakatannya dalam menjalankan perusahaan (Jensen \& Meckling, 1976). Perbedaan kepentingan tersebut akan mempengaruhi pengambilan keputusan dan kebijakan bagi manajemen. Agent dalam perusahaan memiliki tanggungjawab untuk mengoptimalkan keuntungan, perusahaan bisa mengalami kerugian apabila agent hanya mementingkan diri sendiri atau disebut moral hazard (Mafiroh \& Triyono, 2016). Perbedaan tujuan antara pemilik perusahaan akan memunculkan konflik ketika pengelolaan perusahaan yang tidak mampu ditangani langsung oleh pemilik perusahaan. Kecenderungan manajer untuk lebih mementingkan keuntungan pribadi diatas segalanya merupakan asumsi utama dari teori keagenan.

\section{Financial Distress}

Korporasi yang tidak bisa mengelola arus kas operasi menyebabkan kesulitan dalam memenuhi kewajiban lancar kepada kreditur kondisi ini disebut juga financial distress. (Hapsari, 2012). Ketika perusahaan tidak dapat memenuhi kewajibannya yang pada akhirnya akan meningkatkan biaya langsung dan biaya tidak langsung (Kristanti \& Herwany, 2017). Kegagalan perusahaan dalam mempertahankan eksistensinya disebabkan karena tidak mampunya manajemen dalam mengelola sumber daya akan berakibat ketidakefisienan operasional perusahaan sehingga terjadinya financial distress makin besar (Kristanti, 2019:13-14). Kesulitan keuangan termasuk kondisi yang harus dikaji oleh pemilik perusahaan dan manajer apabila tidak tanggap dalam menghadapi hal ini perusahaan akan mengakibatkan risiko kebangkrutan. Untuk mencegah financial distress dapat dilakukan sejak awal dengan mengantisipasi kondisikondisi yang mengarah pada kebangkrutan. Peringatan diperlukan apabila terdapat masalah dalam kinerja keuangan maka manajemen perusahaan mampu melakukan tindakan perbaikan menjadi lebih cepat (Kurniasanti \& Musdholifah, 2018).

\section{Likuiditas}

Kondisi perusahaan yang seringkali mengalami kesulitan finansial yang mengakibatkan suatu perusahaan tidak mempunyai dana yang cukup untuk melunasi kewajibannya bahkan tidak mampu membayar gaji karyawan. Kapabilitas korporasi dalam menuntaskan kewajiban jangka pendeknya bisa dilakukan dengan keseimbangan likuiditas. Rasio yang memperlihatkan kapabilitas sebuah perusahaan guna menuntaskan kewajiban 
finansialnya yang sifatnya jangka pendek secara tepat waktu (Fahmi, 2014:65). Indikator yang diterapkan untuk pengukuran likuiditas menggunakan current ratio yakni melihat kapabilitas perusahaan melunasi hutang kewajiban jangka pendek kepada kreditor yang perhitungannya melalui rasio aset lancar dan kewajiban lancar (Kasmir, 2015:134).

\section{Leverage}

Rasio yang menggambarkan seberapa besar perusahaan membutuhkan penggunaan sumber dana yang dibiayai dalam bentuk hutang (Fahmi, 2014:72). Hutang yang terlalu besar akan berisiko fatal bagi korporasi karena dapat menyebabkan kesulitan untuk melunasi hutang tersebut di masa yang akan datang (Agustini \& Wirawati, 2019). Indikatornya yang dipakai dalam pengukuran leverage dengan menggunakan debt ratio yakni rasio keseluruhan hutang dengan keseluruhan aset (Fahmi, 2014:72).

\section{Komisaris Independen}

Komisaris independen didefinisikan sebagai elemen dari mekanisme corporate governance yang sanggup meminimalisir adanya teori keagenan. Hal ini dikarenakan terdapatnya komisaris independen perusahaan bisa terhindar dari asimetri informasi diantara kedua belah pihak yang bisa memicu financial distress (Hanifah \& Purwanto, 2013). Komisaris independen bertanggungjawab melakukan pengawasan dan memberikan nasihat yang bersifat independen dengan tidak adanya pengaruh dari pihak mana pun terhadap kinerja dari direksi yang dibawahi oleh direktur guna memastikan jika perusahaan menjalankan corporate governance (Mafiroh \& Triyono, 2016).
Kepemilikan Institusional

Kepemilikan institusional ialah persentase nilai sahamnya yang dipegang perusahaan dari jumlah total saham perusahaan yang ada (Chrissentia \& Syarief, 2018). Kepemilikan institusional mempunyai kapabilitas untuk mengontrol manajemen dengan proses pengawasan secara efektif. Kepemilikan institusional dapat meminimalisir biaya agensi dengan cara menggunakan kepemilikan saham yang mewakili sumber kekuasaan agar menunjang posisi manajemen di dalam perusahaan (Fathonah, 2016). Kepemilikan institusional memiliki fungsi yaitu memantau atau memonitor keadaan yang terjadi di dalam perusahaan karena dengan adanya kepemilikan oleh investor institusi bisa meningkatkan kontrol yang semakin maksimal.

\section{Kepemilikan Manajerial}

Kepemilikan saham oleh pihak manajemen mempunyai dua peran yaitu sebagai pemilik perusahaan mempunyai harapan agar nilai saham selalu meningkat sekaligus sebagai pengelola perusahaan yang mempunyai wewenang pada saat pengambilan keputusan, sehingga harus lebih berhati-hati dalam mengambil keputusan dikarenakan mereka bagian dari penanggung risikonya diharapkan dapat membuat keputusan yang terbaik bagi perusahaan (Hadi \& Andayani, 2014). Kepemilikan manajerial diasumsikan dapat mengurangi tindakan agency cost karena mampu mengurangi tindakan kecurangan dari pihak manajer yang akan menimbulkan kerugian bagi perusahaan apabila kondisi ini terjadi berkepanjangan kemungkinan terjadinya financial distress akan mungkin dapat terjadi di masa depan (Kurniasanti \& Musdholifah, 2018). 
Intellectual Capital

Intellectual capital ialah suatu inventaris tak tampak wujudnya yang asalnya dari pengelolaan sumber daya yang optimal, perusahan dapat menggunakannya sebagai nilai tambah untuk membantu meningkatkan kinerja perusahaan (Purba \& Muslih, 2018). Intellectual capital berfungsi mendatangkan value added untuk perusahaan demi memajukan kinerja keuangan guna menunjang keberlangsungan perusahaan dan memperkecil peluang terjadinya financial distress (Mustika et al., 2018).

\section{METODE PENELITIAN}

Penelitian ini didasarkan atas kerangka berpikir. Kerangka pemikiran tersebut menggambarkan pola analisis peneliti dalam menulis karya artikel ini. Dapat dilihat pada gambar 2.

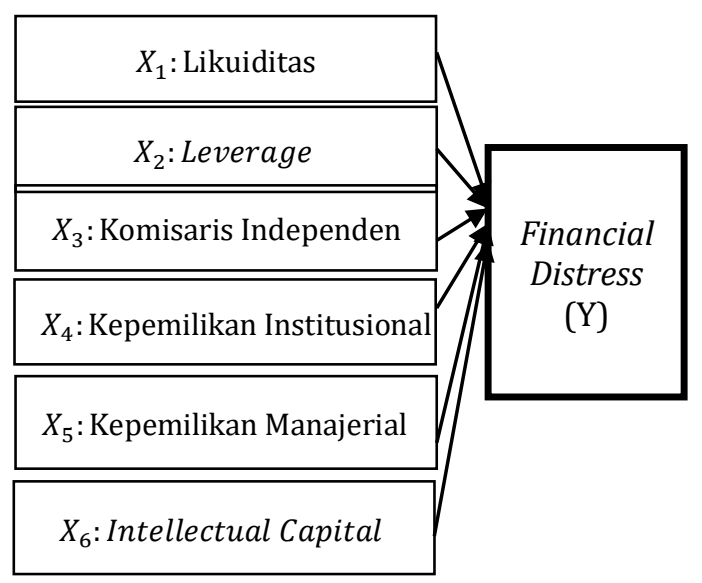

Gambar 2. Kerangka Pemikiran

Pengaruh Likuiditas terhadap Financial Distress

Perusahaan disebut berada pada kondisi likuid bila mampu melakukan pelunasan kewajibannya yang berjangka pendek secara tepat waktu. Tingkat ketersediaan aset lancar yang semakin besar dibandingkan hutang lancar mampu membuat perusahaan tetap berada dalam situasi yang dinyatakan likuid. Apabila perusahaan menyimpan aset lancar yang mudah dijadikan kas lebih besar daripada hutang lancar dianggap mempunyai kemampuan untuk membayarkan hutang lancarnya secara tepat waktu. Semakin tinggi current ratio menggambarkan kinerja yang baik pada korporasi sehingga dapat melunasi kewajibannya secara tepat waktu, sebaliknya apabila current ratio rendah berarti perusahaannya itu tidak sanggup melunasi kewajiban sehingga sulitnya perusahaan dalam pemenuhan kewajibannya yang akan jatuh tempo dan akan memicu timbulnya financial distress.

H1: Adanya pengaruh negatif likuiditas terhadap financial distress

Pengaruh Leverage terhadap Financial Distress

Indikator untuk mengukur leverage memakai debt ratio karena ketika perusahaan berada dalam kondisi terancam kebangkrutan sering disebabkan oleh besarnya hutang hal ini mungkin dapat meminilmalisir kondisi tersebut dengan melunasi hutang yang dimiliki perusahaan dengan asetnya. Besarnya debt ratio maka bertambah besar pula hutang perusahaan hal tersebut akan berisiko perusahaan tersebut memiliki peluang munculnya financial distress sebab tidak sanggup dalam pelunasan kewajiban yang ditanggungnya. Kondisi perusahaan yang terus-menerus mempunyai debt ratio yang tinggi akan mengakibatkan risiko kegagalan pembayaran hutang hingga kreditor kehilangan kepercayaan disebabkan semakin rendahnya perlindungan terhadap kerugian karena mereka menginginkan pengembalian dana secara tepat waktu.

$\mathrm{H} 2$ : Adanya pengaruh positif leverage terhadap financial distress

Pengaruh Komisaris Independen terhadap Financial Distress

Komisaris independen yakni bagian dari dewan komisaris yang memiliki kemampuan untuk bertindak secara 
independen demi keberlangsungan perusahaan. Selain itu, komisaris independen memiliki tujuan pengawasan terhadap kinerja direksi sekaligus memberikan nasihat yang bersifat bebas tidak terpengaruh oleh pihak mana pun. Perusahaan yang mempunyai tingkat proporsinya makin tinggi maka akan lebih memaksimalkan pengawasan dengan begitu dapat mengelola sistem di dalam perusahaan menjadi lebih baik dan kemungkinannya terjadi financial distress semakin rendah.

H3: Adanya pengaruh negatif komisaris independen terhadap financial distress

Pengaruh Kepemilikan Institusional terhadap Financial Distress

Kepemilikan institusional mempunyai fungsi memantau atau memonitor keadaan yang terjadi di dalam perusahaan. Hal ini akan meminimalisir tingkat kecurangan, tindakan yang merugikan atau kesalahan lain yang barangkali dilaksanakan manajer perusahaan. Kepemilikan institusional bisa meningkatkan kontrol perusahaan karena bertambah tingginya taraf kepemilikan institusional akan mendorong perusahaan menjadi lebih efisien untuk melakukan pengawasan yang makin optimal sehingga kemungkinannya terjadi financial distress semakin rendah.

H4: Adanya pengaruh negatif kepemilikan institusional terhadap financial distress

Pengaruh Kepemilikan Manajerial terhadap Financial Distress

Kepemilikan saham dari manajemen berkaitan dengan pengambilan keputusan dan tanggung jawab sebagai pengelola perusahaan yang akan menimbulkan hak dan kewajiban karena memiliki dua peran yakni sebagai pemilik saham dan manajer perusahaan. Besarnya kepemilikan manajerial akan lebih baik dalam sistem kerja perusahaan dengan demikian keuntungan yang didapat akan meningkat. Pengontrolan berbagai kebijakan yang akan dipilih mampu mengurangi tindakan kecurangan dari pihak manajer hal ini berakibat pada kinerjanya perusahaan yang semakin baik dan mampu mengurangi tindakan kecurangan dari pihak manajer, perusahaannya akan terjauhkan dari financial distress.

H5: Adanya pengaruh negatif kepemilikan institusional terhadap financial distress

Pengaruh Intellectual Capital terhadap Financial Distress

Perusahaan yang memiliki pengelolaan sumber daya optimal mampu meningkatkan keuntungan perusahaan dan kepercayaan investor sehingga dapat mengindikasikan perusahaan dalam kondisi sehat. Semakin tinggi intellectual capital berarti semakin baik pula pengelolaan dalam sumber daya manusia sehingga meningkatnya produktivitas karyawan. Kebalikannya, apabila sumber daya perusahaannya yang tidak dikelola secara baik mengakibatkan menurunnya kinerja perusahaan akan memicu financial distress.

H6: Adanya pengaruh negatif intellectual capital terhadap financial distress

Berdasarkan tujuannya riset ini tergolong dalam riset deskriptif dengan memakai data sekunder. Populasinya ialah perusahaan dibidang properti, real estate dan konstruksi serta bidang infrastruktur, utilitas dan transportasi yang tercatat dalam BEI periode 2009-2018.

Cara mengambil sampelnya memakai purposive sampling. Didapatkan 56 sampel perusahaan dari bidang properti, real estate dan konstruksi serta bidang infrastruktur, utilitas dan transportasi yang tercatat pada BEI periode 2009-2018. Berdasar pada periode pelaksanaannya, riset ini termasuk kelompok data panel. Metode riset ini yakni kuantitatif dan memakai data sekunder. Penelitian ini menggunakan analisis statistik deskriptif. Statistik deskriptif yaitu gambaran statistik yang fungsinya menjelaskan berbagai 
data dari sampel berhubungan dengan pengumpulan data dan penyajian data (Sujarweni, 2015:45). tehnik analisis survival yaitu teknik analisa data yang dipakai riset ini. Analisis survival merupakan kumpulan metode statistik dinamis untuk menganalisis dan data dari suatu kejadian. Time to event atau data survival dilakukan pada awal pengamatan hingga terjadinya financial distress. Analisis survival memiliki keunggulan yaitu prosedur analisis statistika dengan adanya konsep penyensoran (Prabawati, Nasution \& Wahyuningsih, 2018). Analisis survival mempunyai tujuan yakni salah satunya adalah untuk mengetahui adanya hubungan antar variabel yang diprediksi mempengaruhi waktu survival dengan waktu survival itu sendiri (Prabawati et al., 2018).

Model analisis survival yang digunakan adalah Cox Proportional Hazard untuk melihat korelasi antar variabel prediktor yang satu dengan lainnya terhadap waktu survival (Marisa et al., 2017).

$$
\begin{aligned}
h(t, x)= & h_{0}(t) \exp \left[\beta_{1} L I Q+\beta_{2} L E V\right. \\
& +\beta_{3} I D P C O M+\beta_{4} I N S T O W N \\
& \left.+\beta_{5} \text { MANOWN }+\beta_{6} I C\right]
\end{aligned}
$$

Dimana:

$\mathrm{h}(\mathrm{t}, \mathrm{x})=$ hazard perusahaan dalam financial distress pada waktu $\mathrm{t}$

$\mathrm{h}_{0}(\mathrm{t}) \quad=$ fungi hazard dasar

$\left[\beta_{1}, \ldots \beta_{p}\right]=$ koefisien regresi atau vektor parameter

LIQ = Likuiditas

LEV = Leverage

INDPCOM $=$ Komisaris Independen

INSTOWN $=$ Kepemilikan Institusional

MANOWN $=$ Kepemilikan Manajerial

\begin{tabular}{|c|c|c|c|c|c|}
\hline & $\mathbf{N}$ & Minimal & Maksimal & Rata-rata & $\begin{array}{c}\text { Std. } \\
\text { Deviation }\end{array}$ \\
\hline LIQ & 56 & .03 & 18.99 & 1.9985 & 2.79794 \\
\hline LEV & 56 & .08 & 2.70 & .5642 & .37396 \\
\hline INDPCOM & 56 & .17 & .75 & .3775 & .10211 \\
\hline INSTOWN & 56 & .09 & .97 & .6340 & .20371 \\
\hline MANOWN & 56 & .00 & .48 & .0410 & .08984 \\
\hline IC & 56 & -14.45 & 22.09 & 2.1267 & 5.3923 \\
\hline $\begin{array}{l}\text { Valid N } \\
\text { (listwise) }\end{array}$ & 56 & & & & \\
\hline
\end{tabular}

IC $\quad=$ Intellectual Capital

TABEL 1. Statistik Deskriptif

\section{HASIL PENELITIAN}

Tabel 1. Memperlihatkan bahwa LIQ, INDPCOM, INSTOWN, MANOWMN, dan IC memiliki angka mean yang lebih kecil dibandingkan dengan standar deviasinya. Menandakan jika variabel tersebut bersifat

\begin{tabular}{|c|c|c|c|c|c|c|c|c|c|}
\hline \multirow{2}{*}{$\begin{array}{c}-2 \log \\
\text { Likelihood }\end{array}$} & \multicolumn{3}{|c|}{ Overall (score) } & \multicolumn{3}{|c|}{ Change From Previous Step } & \multicolumn{3}{|c|}{$\begin{array}{c}\text { Change From Previous } \\
\text { Block }\end{array}$} \\
\hline & Chi-square & df & Sig. & Chi-square & df & Sig. & Chi-square & df & Sig. \\
\hline 178.692 & 21.075 & 6 & .002 & 20.020 & 6 & .003 & 20.020 & 6 & .003 \\
\hline
\end{tabular}
heterogen atau data tidak berkelompok.

TABEL 2. Omnibus Tests of Model Coefficients 


\begin{tabular}{lll}
\hline Hasil pada omnibus tests of model & dalam riset ini terdapat pengaruh terhadap \\
coefficients memperlihatkan jika angka & variabel dependennya dan dapat \\
signifikansinya adalah $0.002 \leq 5 \%$ berarti & menggambarkan sampel pada riset ini fit atau \\
setidaknya satu variabel independennya & sesuai.
\end{tabular}

TABEL 3. Pengujian Hipotesis

\begin{tabular}{lcccccc}
\hline & B & \multicolumn{1}{c}{ SE } & Wald & df & Sig. & $\operatorname{Exp(B)}$ \\
\hline \multicolumn{1}{c}{ LIQ } & .045 & .065 & \multicolumn{1}{c}{.471} & 1 & .493 & 1.046 \\
\hline LEV & 1.632 & .592 & 7.612 & 1 & .006 & 5.117 \\
\hline INDPCOM & 1.562 & 1.871 & .697 & 1 & .404 & 4.768 \\
\hline INSTOWN & 1.547 & 1.213 & 1.625 & 1 & .202 & 4.697 \\
\hline MANOWN & -1.866 & 3.634 & .264 & 1 & .608 & .155 \\
\hline IC & -.111 & .031 & 12.623 & 1 & .000 & .895 \\
\hline \multicolumn{2}{r}{ Sumber: Output SPSS 23(2020) } & & & &
\end{tabular}

\section{PEMBAHASAN}

Pengaruh Likuiditas terhadap Financial Distress

Hasil pengujiannya digambarkan dalam tabel 3 menandakan likuiditas tidak berkaitan pada financial distress, angka sig. $0.493>0.05$. Selaras dengan riset terdahulu dari Chrissentia dan Syarief (2018) menyatakan likuiditas tidak berkaitan pada financial distress. Tetapi, tidak selaras dengan riset terdahulu oleh Agustini dan Wirawati (2019) menyatakan likuiditas mempunyai kaitan pada financial distress. Berdasarkan tabel statistik deskriptif diperoleh sampel penelitian dari dua sektor yang tercatat dalam BEI likuiditas yang nilainya dibawah mean adalah $69.6 \%$ menandakan kondisi yang kurang baik. Hal ini menggambarkan bahwa perusahaan kurang mampu mengelola keuangan terutama current ratio dengan optimal. Perusahaan yang mempunyai current ratio yang rendah artinya tidak mampu melunasi kewajibannya sehingga pemenuhan kewajibannya perusahaan akan sulit ketika jatuh tempo akibatnya kemungkinan terjadi financial distress makin besar. Jadi, tingginya current ratio tidak berdampak pada financial distress.
Pengaruh Leverage terhadap Financial Distress

Hasil pengujiannya digambarkan dalam tabel 3 menandakan leverage mempunyai kaitan pada financial distres dengan arah positif yakni dengan sig. 0.006 $<0.05$. Selaras dengan riset terdahulu oleh Agustini dan Wirawati (2019) menyatakan leverage mempunyai kaitan pada financial distress. Tidak sama dengan riset terdahulu yang dilaksanakan Srikalimah (2017) mengungkapkan leverage tidak mempunyai kaitan pada financial distress. Tingginya tingkat leverage mengakibatkan bertambah tingginya hutang yang harus dipenuhi perusahaannya. Berdasarkan perusahaan yang dijadikan sampel, operasional kegiatannya banyak memakai dana yang berasal dari hutang. Kondisi perusahaan apabila terusmenerus memiliki hutang yang semakin besar mengakibatkan perusahaan tidak mampu membayar hutang di masa depan sehingga perusahaan mempunyai hutang yang lebih besar dibandingkan aset. Salah satu faktor terjadinya financial distress adalah ketidakmampuan perusahaan untuk melunasi kewajibannya.

Pengaruh Komisaris Independen terhadap Financial Distress 
Vol. XVII No. 2 |Bulan Juli tahun 2020

Hasil pengujiannya digambarkan dalam tabel 3 menandakan komisaris independen tidak berkaitan pada financial distress, dilihat dari sig. $0.404>0.05$. Selaras dengan riset terdahulu oleh Ananto, Mustika dan Handayani (2017) menyatakan komisaris independen tidak berkaitan pada financial distress. Tidak selaras dengan riset terdahulu oleh Kristanti dan Isynuwardhana (2018) menyatakan komisaris independen memiliki kaitan pada financial distress. Dalam praktiknya komisaris independen belum dapat menghindari kesulitan keuangan karena keberadaan komisaris independen sifatnya mungkin hanya formalitas. Sehingga, komisaris independen tidak dapat meningkatkan efektivitas dalam fungsi pengawasan yang optimal dan tidak memakai kebebasannya dalam mengontrol kebijakannya direksi.

Pengaruh Kepemilikan Institusional terhadap Financial Distress

Hasil pengujian yang digambarkan dalam tabel 3 menandakan kepemilikan institusional tidak berkaitan pada financial distress, dilihat dari sig. $0.202>0.05$. Selaras dengan riset terdahulu oleh Purba dan Muslih (2018) menyatakan jika kepemilikan institusional tidak berkaitan terhadap financial distress. Berbeda dengan riset terdahulu oleh Chrissentia dan Syarief (2018) menjelaskan kepemilikan institusional memiliki kaitan pada financial distress. Taraf persentase kepemilikan institusional tidak dapat dijadikan tolok ukur agar terbebas dari kemungkinan timbulnya financial distress. Tingginya tingkat persentase yang dimiliki oleh kepemilikan institusional tidak dapat menjadi jaminan pengawasannya yang kuat dari investor institusi. Hal ini menandakan bahwa situasi keuangan perusahaan tidak dapat ditetapkan dari kepemilikan institusional tetapi seluruh keputusannya akan perusahaan disusun oleh pengatur perusahaannya yakni manajer perusahaan.
Pengaruh Kepemilikan Manajerial terhadap Financial Distress

Hasil dari pengujiannya yang digambarkan dalam tabel 3 menandakan kepemilikan manajerial tidak berkaitan dengan financial distress, dilihat berdasarkan angka sig. $0.608>0.05$. Selaras dengan riset terdahulu oleh Cinantya dan Merkusiwati (2015) menyimpulkan jika kepemilikan manajerial tidak berkaitan pada financial distress. Tidak selaras dengan riset terdahulu dari Fuad (2014) menyimpulkan jika kepemilikan manajerial memiliki kaitan pada financial disitress. Saham yang dimiliki manajer akan mempunyai dua peranan yakni sebagai pemilik saham dan manajer perusahaan. Manajer yang memiliki kepemilikan saham yang terlalu kecil akan menyebabkan mereka cenderung untuk mementingkan keuntungan pribadi bahkan tidak mampu dalam mengendalikan kebijakan keuangan sehingga tidak mampu melakukan tugasnya dengan baik. Proporsi kepemilikan manajerial yang masih tergolong rendah merupakan salah satu faktor belum memiliki kaitan pada financial distress.

Pengaruh Intellectual Capital terhadap Financial Distress

Hasil dari pengujiannya digambarkan dalam tabel 3 menandakan intellectual capital mempunyai kaitan pada financial distress dengan arah negatif dilihat dari angka sig. $0.000<0.05$. Selaras dengan riset terdahulu oleh Purba dan Muslih (2018), Mustika et al. (2018) menyimpulkan jika intellectual capital adanya dampak pada financial distress. Pengelolaan intellectual capital yang baik artinya semakin baik pula pengelolaan sumber daya manusia sehingga meningkatnya produktivitas karyawan. Perusahaan yang memiliki manajemen dan sumber daya berkemampuan yang baik akan menambah kinerja perusahaannya, keuntungan dan 
kepercayaan investor sehingga mampu meminimalisir timbulnya financial distress.

\section{KESIMPULAN}

Berdasar pada riset yang telah dilaksanakan memperlihatkan jika leverage dapat memperkirakan timbulnya financial distress yang mengarah positif dan intellectual capital dapat memperkirakan munculnya financial distress yang mengarah negatif. Namun, likuiditas, komisaris independen, kepemilikan institusional tidak mempunyai dampak dalam memprediksi financial distress.

Perusahaan diharapkan supaya meningkatkan modal intelektualnya dari sumber daya agar mampu mengorganisasikan perusahaan dan mengendalikan sistem kerja keuangannya secara baik supaya terhindar dari financial distress dengan begitu bisa mengembalikan keyakinan investor supaya melakukan investasi. Perusahaan harus mampu mengelola keuangan agar leverage tetap berada pada tingkat yang rendah karena rendanya nilai leverage dimungkinkan menyebabkan timbulnya financial distress makin berkurang. Penting untuk perusahaan guna mempertimbangkan taraf leverage guna mencegah terjadinya kebangkrutan.

\section{DAFTAR PUSTAKA}

Agustini, N. W. \& Wirawati, N. G. P., 2019. Pengaruh Rasio Keuangan Pada Financial Distress Perusahaan Ritel Yang Terdaftar di Bursa Efek Indonesia (BEI). E-Jurnal Akuntansi Universitas Udayana, pp. 251-280.

Aletheari, I. A. M. \& Jati, I. K., 2016. Pengaruh Earning Per Share, Price Earning Ratio, dan Book Value Per Share Pada Harga Saham. E-Jurnal Akuntansi Universitas Undayana, 17(2), pp. 1254-1282.

Chrissentia, T. \& Syarief, J., 2018. Analisis Pengaruh Rasio Profitabilitas, Leverage, Likuiditas, Firm Age, Dan Kepemilikan Institusional Terhadap Financial Distress.
Jurnal Sistem Informasi, Manajemen dan Akuntansi (SiMAk), 16(1), pp. 45-61.

Cinantya, I. G. A. A. P. \& Merkusiwati, N. K. L. A., 2015. Pengaruh Corporate Gvernance, Financial Indicators, dan Ukuran Perusahaan Pada Financial Ditress. E-Jurnal Akuntansi Universitas Udayana, 10(3), pp. 987-915.

Fahmi, I., 2014. Pengantar Manajemen Keuangan (Cetakan ke-3). Bandung: Alfabeta.

Fathonah, A. N., 2016. Pengaruh Penerapan Good Corporate Governance Terhadap Financial Distress. Jurnal Ilmiah Akuntansi, 1(2), pp. 133-150.

Hadi, S. \& Andayani, 2014. Mekanisme Corporate Governance dan Kinerja Keuangan Pada Perusahaan Yang Mengalami Financial Distress. Jurnal Ilmu dan Riset Akuntansi, 3(5), pp. 1-17.

Hanifah, O. E. \& Purwanto, A., 2013. Pengaruh Struktur Corporate Governance Dan Financial Indicators Terhadap Kondisi Financial Distress. Diponegoro Journal of Accounting, 2(2), pp. 1-15.

Hapsari, E. I., 2012. Kekuatan Rasio Keuangan Dalam Memprediksi Kondisi Financial Distress Perusahaan Manufaktur Di BEI. Jurnal Dinamika Manajemen, 3(2), pp. 101-109.

Jensen, M. C. \& Meckling, W. H., 1976. Theory Of The Firm: Managerial Behavior, Agency Cost, and Ownership Structure. Journal of Financial Economics 3, Volume 3, pp. 303-360.

Kasmir, 2015. Analisis Laporan Keuangan. Jakrta: Grasindo.

Kristanti, F. T., 2019. Financial Distress (Teori dan Perkembangan dalam Konteks Indonesia). Malang: Inteligensia Media.

Kristanti, F. T., Effendi, N., Hermany, A. \& Febrian, E., 2016. Does Coporate Governance Affect the Financial Distress of Indonesian Company? A survival Analysis Using Cox 
Hazard Model With Time-Dependent Covariates. Advanced Science Letters, Volume 22, pp. 4326-4329.

Kristanti, F. T., Rahayu, S. \& Huda, A. N., 2016. The Determinant of Financial Distress on Indonesian Family Firm. Procedia - Social and Behavioural Sciences, Volume 219, pp. 440-447.

Kristanti, T. F. \& Herwany, A., 2017. Corporate Governance, Financial Ratios, Political Risk and Financial Distress : A Survival Analysis. Accounting and Finance Review, 2(2), pp. 26-34.

Kurniasanti, A. \& Musdholifah, M., 2018. Pengaruh Corporate Governance, Rasio Keuangan, Ukuran Perusahaan dan Makroekonomi Terhadap Financial Dsitress. Jurnal Ilmu Manajemen, 6(3), pp. 197-212.

Mafiroh, A. \& Triyono, 2016. Pengaruh Kinerja Keuangan dan Mekanisme Corporate Governance Terhadap Financial Distress. Riset Akuntansi dan Keuangan Indonesia, 1(1), pp. 46-53.

Marisa, Yozza, H. \& Maiyastri, 2017. Model Regresi Cox Proportional Hazard Pada Laju Tamat Mahasiswa Jurusan Matematika Universitas Andalas. Jurnal Matematika UNAND, 6(1), pp. 33-41.

Mustika et al., R., 2018. Pengaruh Modal Intelektual Terhadap Financial Ditress (Studi Pada Perusahaan Pertambangan dan
Manufaktur). Jurnal Ekonomi \& Bisnis Dharma Andalas, 20(1), pp. 120-130.

Platt, H. D. \& Platt, M. B., 2002. Predicting Financial Distress. Journal of Financial Service Profesionals, Volume 56, pp. 12-15.

Prabawati, S., Nasution, Y. N. \& Wahyuningsih, S., 2018. Analisis Survival Data Kejadian Bersama dengan Pendekatan Enron Partial Likehood. Jurnal EKSPONENSIAL, 9(1), pp. 75-84.

Purba, S. I. M. \& Muslih, M., 2018. Pengaruh Kepemilikan Institusional , Intellectual Capital, dan Leverage Terhadap Financial Distress. Journal Accounting and Finance, 2(2), pp. 27-40.

Saleh, D. S., 2018. Pengaruh Operating Capacity, Arus Kas Operasi dan Biaya Variabel Terhadap Financial Distress Pada Perusahaan Manufaktur Subsektor Textil dan Garment yang Terdaftar Di Bursa Efek Indonesia (BEI) Tahun 2009-2016. Jurnal Ekonomi dan Bisnis, Vol. 8 No. 1 Maret 2018, 18(1), pp. 34-49.

Sujarweni, W., 2017. Analisis Laporan Keuangan. Yogyakarta: Pustaka Baru Press.

Widhiari, N. L. M. A. \& Merkusiwati, N. K. L. A., 2015. Pengaruh Rasio Likuiditas, Leverage, Operating Capacit, dan Sales Growth Terhadap Financial Distress. EJurnal Akuntansi Universitas Udayana, 11(2), pp. 456-496. 